\title{
Internet Use by Parents of Children With Rare Conditions: Findings From a Study on Parents' Web Information Needs
}

Honor Nicholl, RCN, RGN, MEd, PhD; Catherine Tracey, RGN, RPN, MSc, MBA, PhD; Thelma Begley, RGN, RCN, RNT, BNS (Hons), MSc; Carole King, RCN, RGN, RCT, RNT, MSc; Aileen M Lynch, BSc (Hons), MSc, $\mathrm{PhD}$

School of Nursing and Midwifery, Trinity College Dublin, the University of Dublin, Dublin, Ireland

\section{Corresponding Author:}

Aileen M Lynch, BSc (Hons), MSc, PhD

School of Nursing and Midwifery

Trinity College Dublin, the University of Dublin

24 D'Olier Street

Dublin, D2

Ireland

Phone: 35318968571

Fax: 35318963001

Email: amlynch@tcd.ie

\section{Abstract}

Background: Parents of children with rare conditions increasingly use the Internet to source information on their child's condition. This study reports on part of a larger study whose overall aim was to identify the Internet use by parents when seeking information on their child's rare condition, with the specific purpose of using the findings to aid in the development of a website specifically designed to meet the parents' needs. It presents findings on why these parents use the Internet, the information and support content they source, and the impact these resources have on their capacity to care for and manage their child's condition.

Objective: To (1) ascertain parents' general Internet usage patterns, (2) identify the nature of the information parents most frequently searched for, and (3) determine the effect the Internet-sourced information had on parents of children with rare conditions.

Methods: Data collection was conducted in 2 parts: Part 1 was a focus group interview $(n=8)$ to inform the development of the questionnaire, and Part 2 was a questionnaire (Web- and paper-based). All respondents $(\mathrm{N}=128)$ completed the questionnaire using the Internet.

Results: Parents frequently and habitually used the Internet and social media to gather information on their child's condition. These Web-based resources provide parents with a parent-to-parent support platform that allows them to share their experiences and information with other parents, which, the respondents considered, improved their knowledge and understanding of their child's condition. The respondents also reported that these resources positively impacted on their decision making, care, and management of their child's condition. However, they reported receiving mixed responses when wishing to engage and share with health care professionals their Internet and social media interactions and information outcomes.

Conclusions: This study adds to the emerging body of research on the Internet use by parents of children with rare conditions to source information on their child's condition. The evolving and ever increasing parent-to-parent support systems via social media are impacting on parents' capacity to manage their children. Implications for practice include health care professionals' response to this knowledge and capacity shift, and the significance of these changes when interacting with parents. The key message of this study was that parents of children with rare conditions are habitual users of the Internet to source information about their children's conditions. Social media, especially Facebook, has an increasing role in the lives of these parents for information and support. Parents' interest in information gathering and sharing includes a desire for shared dialogue with health care professionals.

(J Med Internet Res 2017;19(2):e51) doi: 10.2196/jmir.5834

\section{KEYWORDS}

rare diseases; parents; Internet; consumer health information; social media; professional-patient relations 


\section{Introduction}

The Internet is recognized as a significant source of health information [1] and may assist parents of children with rare conditions (rare conditions includes rare diseases and rare disorders in this paper) to find information, clarify, and understand the information they have been given, or confirm a diagnosis [2,3]. Parents of these children can experience difficulties with aspects of their child's diagnosis and management, as each condition is rare and diverse in symptoms. Traditionally, health care professionals have been the gatekeepers of specialized knowledge about the child's rare condition [4]. In some cases, the rareness of the child's condition means that information is difficult to find, even for health care professionals, thus making diagnosis and management of the child and his or her condition difficult $[4,5]$.

The Internet is changing the way parents of children with rare conditions access information. It enables them access worldwide information that previously was unavailable to them [6,7]. In comparison to more traditional sources, the Internet may provide large volumes of information from a variety of sources and perspectives, for example, emerging treatment options or relevant clinical trials. This information can be accessed as required, and anonymously and confidentially, if desired. In addition, it is cost-effective and convenient and can be accessed without having to leave one's home [8]. However, when there is no monitoring of the quality or reliability of Internet-based information, the resultant information can be questionable. Parents can also be overwhelmed with both the amount of information available as well as the presentation of case studies of children with more complex or advanced presentations of conditions similar to those of their child.

Through the use of smartphones and mobile devices, information searching via social media and search engines is now a daily occurrence for many people [1]. Additionally, social networks can be established with other parents. Nationally and internationally based Facebook groups or pages are now common for rare conditions [7,9]. Furthermore, parents are using the Internet to receive information and emotional support from Web-based groups of parents facing similar challenges, while also critiquing care provision and health care policy [10]. However, information may not be presented in a balanced way via social networks. Thus, parents need to establish how reliable the information they are acquiring from Internet or social media resources is.

The aim of this study was to identify the Internet-sourced information and support content that meets the needs of parents of children with rare conditions for the purposes of developing an Irish website specifically designed to meet those needs. The objectives were to (1) ascertain parents' general Internet usage patterns, (2) identify the nature of the information parents most frequently searched for, and (3) determine the effect the Internet-sourced information had on parents of children with rare conditions.

\section{Methods}

This descriptive exploratory study used both qualitative and quantitative designs. Purposive nonprobability sampling was adopted where participant recruitment was facilitated by the Saoirse Foundation, which acted as the study's gatekeeper. The study was advertised for 4 weeks on the gatekeeper's website and in various linked voluntary organizations and social media links (Twitter, Facebook, blogs). The inclusion criterion was parents (18 years or older) of a child with a rare condition who used the Internet to source information about their child's condition. A more detailed information leaflet was provided to the gatekeeper to distribute to parents who wished to know more about the study. Parents who wanted to participate in the study contacted the researcher and were scheduled to either (1) attend a focus group or (2) complete a questionnaire (Multimedia Appendix 1) that was open for 4 weeks.

The questionnaire was modeled on 2 previously published questionnaires by Porter and Edirippulige [11] and Tozzi et al [12], and 8 participants took part in the focus group to further refine the questionnaire. Written consent was sought prior to the commencement of the focus group. Once the focus group was completed, responses were fed back to the group, thus allowing participants verify their discussion, which was subsequently analyzed and categorized into themes (simple thematic analysis) [13].

The questionnaire consisted of 45 questions that were in the multiple-choice format apart from 2 open questions: (1) the website(s) I most frequently visit is(are) and (2) if you were creating a website for parents of children with rare conditions, what is the ONE thing you would like to see on that website? The resultant responses were analyzed by simple thematic analysis [13]. The questionnaire was divided into 4 sections, and although 128 respondents started the questionnaire, 93 respondents completed the questionnaire in full. Section 1 contained questions to confirm that the respondent was a parent of a child with a rare condition and used the Internet to source information about their child's condition (inclusion criterion). A total of 7 respondents did not meet this inclusion criterion and were disqualified. So, the remaining respondents were only parents (Table 1). 
Table 1. Overview of the questionnaire.

\begin{tabular}{llll}
\hline $\begin{array}{l}\text { Section num- } \\
\text { ber }\end{array}$ & Section title & $\begin{array}{l}\text { Number of ques- } \\
\text { tions }\end{array}$ & $\begin{array}{l}\text { Number of respondents who commenced the } \\
\text { section }\end{array}$ \\
\hline 1 & Sources of information about your child's condition & 3 & $\begin{array}{l}128 \\
(7 \text { disqualified, as they did not fulfill the in- } \\
\text { clusion criterion) }\end{array}$ \\
& & 121 \\
2 & $\begin{array}{l}\text { Information about your use of the Internet to find information about } \\
\text { your child's condition }\end{array}$ & 23 & 96 \\
4 & Information about your child or children & 8 (per child) & 96 \\
& Information about yourself & 11 & 93 \\
\hline
\end{tabular}

Although participants had the option of completing Web- or paper-based versions of the questionnaire, all chose the Web-based option on SurveyMonkey (SurveyMonkey Inc). Ethical approval was obtained from the School of Nursing and Midwifery's Research Ethics Committee, Trinity College Dublin, Ireland.

\section{Results}

\section{Demographical Details}

In Section 4 of the questionnaire, 93 respondents offered information about themselves (Table 2). The majority were mothers $(87 \%, 81 / 93)$, aged between 35 and 49 years $(67 \%$, $62 / 93)$, living in urban areas $(74 \%, 69 / 93)$ mostly in the Republic of Ireland $(84 \%, 78 / 93)$. Half of the respondents $(50 \%$, 46/93) had a University degree, and 43\% (40/93) were their child's main carer (Table 2). Respondents who were not employed full time $(84 \%, 78 / 93)$ were asked whether they left full-time employment to care for their child. Of these, $65 \%$ (51/78) selected yes, and the remaining 35\% (27/78) selected either no or not applicable. 
Table 2. Parents' demographics ( $\mathrm{n}=93)$.

\begin{tabular}{|c|c|c|}
\hline Demographics & & $\mathrm{n}(\%)$ \\
\hline \multicolumn{3}{|l|}{ Gender } \\
\hline & Females & $81(87)$ \\
\hline & Males & $12(13)$ \\
\hline \multicolumn{3}{|l|}{ Age (in years) } \\
\hline & $18-34$ & $22(24)$ \\
\hline & $35-49$ & $62(67)$ \\
\hline & $50-64$ & $9(10)$ \\
\hline \multicolumn{3}{|c|}{ Country of residence } \\
\hline & Republic of Ireland & $78(84)$ \\
\hline & Northern Ireland & $6(7)$ \\
\hline & United Kingdom & $7(8)$ \\
\hline & United States & $2(2)$ \\
\hline \multicolumn{3}{|c|}{ Area of residence } \\
\hline & City & $20(22)$ \\
\hline & Town & $30(32)$ \\
\hline & Village & $19(20)$ \\
\hline & Rural & $24(26)$ \\
\hline \multicolumn{3}{|c|}{ Highest level of education } \\
\hline & Secondary school & $23(25)$ \\
\hline & Vocational training & $24(26)$ \\
\hline & University: Undergraduate degree & $25(27)$ \\
\hline & University: Postgraduate degree & $21(23)$ \\
\hline \multicolumn{3}{|c|}{ Employment status } \\
\hline & Employed full time & $15(16)$ \\
\hline & Employed part time & $20(22)$ \\
\hline & Self-employed & $3(3)$ \\
\hline & Your child or children's main carer & $40(43)$ \\
\hline & Homemaker & $12(13)$ \\
\hline & Student & $1(1)$ \\
\hline & Unemployed & $2(2)$ \\
\hline
\end{tabular}

In total, 117 children were reported on by their parents (Table 3 ). Furthermore, 78 parents reported on 1 child, 14 parents reported on 2 children, 1 parent reported on 3 children, and 2 parents reported on 4 children. Over half $(54.7 \%, 64 / 117)$ the children were male and ranged in age from less than 12 months to 39 years, with the 4- to 7-year-old category being the largest (28.2\%, 33/117). Ninety per cent (105/117) of children had a diagnosis, and $65.7 \%$ (69/105) received a diagnosis in their first 3 years of life. The majority $(78.6 \%, 92 / 117)$ of children had a disability, and of these, a little more than half $(53 \%, 49 / 92)$ had a physical and intellectual disability, 30\% (28/92) had a physical disability, 10\% (9/92) had an intellectual disability, and there was an equal spread (3\%, 3/92) across sensory and neurodevelopmental disabilities, respectively. Some children (39.3\%, 46/117) did not need assistive equipment. The remaining 71 children mainly needed equipment for moving (41.0\%, 48/117), eating (19.7\%, 23/117), and breathing (11.1\%, 13/117; Table 3). 
Table 3. Children's demographics.

\begin{tabular}{|c|c|c|}
\hline Demographics & & $\mathrm{n}(\%)$ \\
\hline \multicolumn{3}{|c|}{ Gender $(n=117)$} \\
\hline & Female & $53(45.3)$ \\
\hline & Male & $64(54.7)$ \\
\hline \multicolumn{3}{|l|}{ Age $(n=117)$} \\
\hline & Under 12 months & $5(4.3)$ \\
\hline & $1-3$ & $24(20.5)$ \\
\hline & $4-7$ & $33(28.2)$ \\
\hline & $8-12$ & $28(23.9)$ \\
\hline & 13-19 & $15(12.8)$ \\
\hline & $20-29$ & $9(7.7)$ \\
\hline & $30-39$ & $3(2.6)$ \\
\hline \multicolumn{3}{|c|}{ Does child have a diagnosis $(n=117)$} \\
\hline & No & $12(10.3)$ \\
\hline & Yes & $105(89.7)$ \\
\hline \multicolumn{3}{|c|}{ If yes, age at diagnosis $(n=105)$} \\
\hline & Under 12 months & $36(34.3)$ \\
\hline & $1-3$ & $33(31.4)$ \\
\hline & $4-7$ & $16(15.2)$ \\
\hline & $8-12$ & $15(14.3)$ \\
\hline & $13-19$ & $4(3.8)$ \\
\hline & $20-29$ & $1(0.9)$ \\
\hline \multicolumn{3}{|c|}{ Does the child's condition include a disability $(n=117)$} \\
\hline & No & $25(21.4)$ \\
\hline & Yes & $92(78.6)$ \\
\hline \multicolumn{3}{|c|}{ If yes, what is the nature of the disability $(n=92)$} \\
\hline & Physical and intellectual & $49(53)$ \\
\hline & Physical & $28(30)$ \\
\hline & Intellectual & $9(10)$ \\
\hline & Sensory & $3(3)$ \\
\hline & Neurodevelopmental & $3(3)$ \\
\hline \multicolumn{3}{|c|}{ Does your child use equipment for ${ }^{a}(n=117)$} \\
\hline & None required & $46(39.3)$ \\
\hline & Moving & $48(41.0)$ \\
\hline & Eating & $23(19.7)$ \\
\hline & Breathing & $13(11.1)$ \\
\hline & Speech & $10(8.6)$ \\
\hline & Sitting & $7(5.9)$ \\
\hline & Hearing & $6(5.1)$ \\
\hline & Bathing; sleeping & $3(2.6)$ \\
\hline & Writing; nonverbal; seeing & $2(1.7)$ \\
\hline & Sensory integration & $1(0.9)$ \\
\hline
\end{tabular}




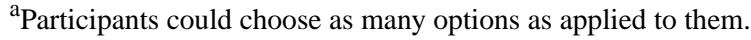

\section{Internet Use}

Respondents' Internet usage is summarized in Table 4. The Internet was used predominantly at home $(92.9 \%, 106 / 114)$, between 7 pm to midnight $(42.9 \%, 49 / 114)$ and searched on a weekly basis $(50.0 \%, 57 / 114$; either daily, several times, or once per week) mostly on a PC or Mac (41.4\%, 46/111). When searching the Internet for information on their child's condition,
$45.6 \%$ (52/114) sometimes found relevant information whereas $37.7 \%$ (43/114) found relevant information most of the time. All respondents $(n=112)$ had an email address and $94.6 \%$ $(106 / 112)$ had a Facebook account. Most $(93.1 \%, 95 / 102)$ used general search engines (Google, Yahoo, Bing), and $28.4 \%$ (29/102) accessed specialized sites (Table 4). A total of 75 named websites were accessed (Multimedia Appendix 2). 
Table 4. Internet use.

Internet usage $\mathrm{n}(\%)$

From where do you most often access the Internet? $(n=114)$

$\begin{array}{ll}\text { Home } & 106(92.9) \\ \text { Work } & 7(6.1) \\ \text { Public library } & 0(0) \\ \text { Other (Smartphone) } & 1(0.9) \\ & \\ \text { Midnight to } 6 \text { am } & 2(1.8) \\ 7 \text { am to midday } & 7(6.1) \\ 1 \text { pm to } 6 \text { pm } & 10(8.8) \\ 7 \text { pm to midnight } & 49(42.9) \\ \text { No pattern } & 46(40.4)\end{array}$

How often do you use the Internet to find information about your child's condition? $(n=114)$

$\begin{array}{ll}\text { Every day } & 23(20.2) \\ \text { Once a week } & 9(7.9) \\ \text { Several times a week } & 25(21.9) \\ \text { Once a month } & 10(8.8) \\ \text { Several times a month } & 13(11.4) \\ \text { Every few months } & 25(21.9) \\ & 9(7.9)\end{array}$

What device do you use MOST OFTEN to access the Internet? $(n=111)$

$\begin{array}{ll}\text { PC or Mac } & 46(41.4) \\ \text { Smartphone } & 42(37.8) \\ \text { Tablet (iPad or similar) } & 23(20.7)\end{array}$

When using the Internet, how often are you able to find the information you are looking for? $(n=114)$

$\begin{array}{ll}\text { Always } & 2(1.8) \\ \text { Most of the time } & 43(37.7) \\ \text { Sometimes } & 52(45.6) \\ \text { Hardly ever } & 15(13.2) \\ \text { Never } & 2(1.8) \\ & \\ \text { Email } & 112(100.0) \\ \text { Facebook } & 106(94.6) \\ \text { Twitter } & 48(42.9) \\ \text { Skype } & 57(50.9) \\ \text { LinkedIn } & 31(27.7) \\ \text { MSN or Messenger } & 23(20.5) \\ \text { Blog } & 12(10.7) \\ \text { Health-related apps } & 9(8.0)\end{array}$

How do you locate information about your child's condition $?^{\mathrm{a}}(\mathbf{n}=102)$ 


\begin{tabular}{|c|c|c|}
\hline \multirow[t]{2}{*}{ Internet usage } & & $\mathrm{n}(\%)$ \\
\hline & $\begin{array}{l}\text { Search engines (Google, Yahoo, } \\
\text { Bing, etc) }\end{array}$ & $95(93.1)$ \\
\hline & Specialized websites & $29(28.4)$ \\
\hline & Orphanet & $7(6.9)$ \\
\hline & Social media & $7(6.9)$ \\
\hline & Recommendations from others & $4(3.9)$ \\
\hline
\end{tabular}

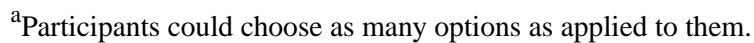

Respondents were asked to rank which factors they took into account when choosing a website and could choose as many factors as applied to them. Of the 112 respondents who replied to this question, $65.2 \%$ (73/112) respondents ranked relevant and accurate as being the most important factor, closely followed by trustworthiness $(62.5 \%, 70 / 112)$ and the website being up to date $(60.7 \%, 68 / 112)$. In order of ranking, other factors included the website being recommended to me by $a$ health professional (46.4\%, 52/112), easy to understand (37.5\%, $42 / 112)$, has other websites linked within it $(8.0 \%, 9 / 112)$, and has a nice layout $(5.4 \%, 6 / 112)$.

Respondents $(\mathrm{n}=101)$ ranked which information they searched for (1) when their child was first diagnosed or when they first had a concern about their child's health and (2) what they search for at present (Table 5). 
Table 5. Information topics sought by parents of children with rare conditions on the Internet ( $\mathrm{n}=101$; Participants who answered the questions could choose as many options as applied to them)

\begin{tabular}{|c|c|c|c|c|c|c|}
\hline Rank & $\mathrm{n}^{\mathrm{a}}$ & Information searched for when first diagnosed & $\begin{array}{l}\text { Change } \\
\text { in rank }\end{array}$ & Rank & $\mathrm{n}^{\mathrm{a}}$ & Information searched for now \\
\hline 1 & 87 & My child's condition or symptoms & $\leftrightarrow$ & 1 & 71 & My child's condition or symptoms \\
\hline 2 & 77 & My child's diagnosis & $\downarrow 2$ & 2 & 70 & The management of my child's condition \\
\hline 3 & 69 & The management of my child's condition & $\uparrow 1$ & 3 & 51 & $\begin{array}{l}\text { The care of my child's condition } \\
\text { Treatments }\end{array}$ \\
\hline 4 & 66 & $\begin{array}{l}\text { Treatments } \\
\text { Support groups }\end{array}$ & $\begin{array}{l}\uparrow 1 \\
\downarrow 1\end{array}$ & 4 & 47 & My child's diagnosis \\
\hline 5 & 64 & Genetics & $\downarrow_{3}$ & 5 & 43 & Support groups \\
\hline 6 & 57 & $\begin{array}{l}\text { The care of my child's condition } \\
\text { Child development }\end{array}$ & $\begin{array}{l}\uparrow 3 \\
\leftrightarrow\end{array}$ & 6 & 42 & Child development \\
\hline 7 & 46 & Organizations and societies & $\downarrow 2$ & 7 & 36 & Research and innovation \\
\hline 8 & 40 & Medical or health care professionals & $\downarrow 2$ & 8 & 35 & Genetics \\
\hline 9 & 33 & Research and innovation & $\uparrow 2$ & 9 & 33 & $\begin{array}{l}\text { Educational options } \\
\text { Organizations and or societies }\end{array}$ \\
\hline 10 & 31 & Early intervention options & $\downarrow 7$ & 10 & 30 & Medical or health care professionals \\
\hline 11 & 30 & Physical activities & $\downarrow_{1}$ & 11 & 29 & $\begin{array}{l}\text { Preventing complications } \\
\text { Upcoming events or workshops }\end{array}$ \\
\hline 12 & 29 & Hospitals, hospices, medical centers & $\downarrow 3$ & 12 & 28 & Physical activities \\
\hline 13 & 28 & $\begin{array}{l}\text { Medicines or alternative treatments or therapies } \\
\text { Nutrition }\end{array}$ & $\begin{array}{l}\downarrow 1 \\
\leftrightarrow\end{array}$ & 13 & 27 & Nutrition \\
\hline 14 & 27 & Preventing complications & $\uparrow 3$ & 14 & 22 & $\begin{array}{l}\text { Medicines or alternative treatments or therapies } \\
\text { Financial assistance }\end{array}$ \\
\hline 15 & 26 & Future pregnancies & $\downarrow_{2}$ & 15 & 21 & $\begin{array}{l}\text { Hospitals, hospices, medical centers } \\
\text { State services }\end{array}$ \\
\hline 16 & 25 & Educational options & $\uparrow 7$ & 16 & 17 & Managing family dynamics \\
\hline 17 & 24 & $\begin{array}{l}\text { State services } \\
\text { Financial assistance }\end{array}$ & $\begin{array}{l}\uparrow 2 \\
\uparrow 3\end{array}$ & 17 & 12 & $\begin{array}{l}\text { Early intervention options } \\
\text { Future pregnancies }\end{array}$ \\
\hline 18 & 16 & Where to get a second opinion & $\downarrow 2$ & 18 & 11 & $\begin{array}{l}\text { Accessing medicines or alternative treatments or ther- } \\
\text { apies on the Internet }\end{array}$ \\
\hline 19 & 15 & Upcoming events or workshops & $\uparrow 8$ & 19 & 8 & Vaccinations \\
\hline 20 & 12 & Managing family dynamics & $\uparrow 4$ & 20 & 7 & Where to get a second opinion \\
\hline 21 & 11 & $\begin{array}{l}\text { Accessing medicines or alternative treatments or ther- } \\
\text { apies on the Internet }\end{array}$ & $\uparrow 3$ & & & \\
\hline 22 & 10 & Vaccinations & $\uparrow 3$ & & & \\
\hline
\end{tabular}

${ }^{\mathrm{a}}$ Represents the number of participants who chose each information topic.

Overall there was not great variation in the ranking of information searched for over the 2 timelines. The first 10 ranked information topics underwent some minor reordering but remained in the top 10 across both timelines (apart from early intervention options), and my child's condition or symptoms remained the highest ranked. Early interventions options ranked 10 when first diagnosed but decreased in ranking to 17 at the later time point.

Other topics increased in the rankings, for example, managing family dynamics ranked at 20 at the time of diagnosis compared with 16 at present. The greatest difference in ranking (7) was for educational options, which ranked 16 at time of diagnosis, but at present ranked 9. Similarly, upcoming events or workshops increased in ranking by 8 from 19 at the time of diagnosis to 11 at present. Interestingly future pregnancies changed little across timelines, ranking 15 at the time of diagnosis versus 17 at present.

\section{Impact}

Having considered respondents' usage of the Internet, next the respondents were asked whether Internet-sourced information influenced decisions they made about their child's condition, and 98 of them replied. Most respondents considered that 
Internet-sourced information had some degree of influence, be it a minor or some influence $(67 \%, 66 / 98)$ or a major influence $(20 \%, 20 / 98)$, whereas for $10 \%$ (10/98), it had no influence and $2 \%$ (2/98) did not know.

Parents were asked about the impact on them of information found on the Internet by choosing relevant statements from a list, and they could choose as many as applied to them. In total, 86 parents replied to this question, and their choices are ranked in the order of popularity in Table 6. For 72\% (62/86) of respondents, Internet-sourced information improved their understanding of their child's condition. The next 2 highly ranked options were enabled me to explain my child's condition $(58 \%, 50 / 86)$ and improved my ability to manage and care for my child's condition $(57 \%, 49 / 86)$. For approximately a third of respondents $(33 \%, 28 / 86)$, the impact of Internet-sourced information had served to increase their anxiety, while for $16 \%$ (14/86), it decreased their anxiety.

Table 6. The impact of Internet-sourced information on parents ( $n=86$; Participants could choose as many options as applied to them)

\begin{tabular}{|c|c|c|}
\hline Rank & Impact & $\mathrm{n}(\%)$ \\
\hline 1 & Improved my understanding of my child's condition & $62(72)$ \\
\hline 2 & Enabled me to explain my child's condition & $50(58)$ \\
\hline 3 & Improved my ability to manage and care for my child's condition & $49(57)$ \\
\hline 4 & Increased my anxiety & $28(33)$ \\
\hline 5 & Was useful for diagnosing my child's condition & $20(23)$ \\
\hline \multirow[t]{2}{*}{6} & Decreased my anxiety & $14(16)$ \\
\hline & Was useful for accessing medicines or alternative treatments or therapies on the Internet & \\
\hline 7 & Made me change my medical or health care professional & $8(9)$ \\
\hline 8 & Made me change my child's food habits & $6(7)$ \\
\hline 9 & Made me change my child's physical activity & $5(6)$ \\
\hline \multirow[t]{2}{*}{10} & Was not useful & $4(5)$ \\
\hline & Not sure & \\
\hline 11 & Empowered me & $2(2)$ \\
\hline \multirow[t]{2}{*}{12} & Helped me educate my health care professional & $1(1)$ \\
\hline & Useful for making new contacts & \\
\hline
\end{tabular}

\section{Parents Disseminating Internet-Sourced Information}

Respondents used the Internet to communicate and link with others, for example, via email, Facebook, Twitter, and so forth (Table 4). More specifically, the respondents were asked whether they were registered in a Web-based forum or a social network group dedicated to their child's condition, and of the 112 who answered this question, $80.4 \%$ (90/112) were. Of these 90 respondents, $86 \%$ (77/90) shared information about their child's condition with these Internet communities.

In the context of health care, the respondents were asked whether they told their doctor or health care professional about the information they found on the Internet regarding their child's condition. Seventy-six $(78 \%, 76 / 97)$ who answered this question had relayed Internet-sourced information about their child, but there was variability regarding the degree of interest the doctor or health care professional had in the information. Of the 76 respondents, 50\% (38/76) felt that their doctor or health care professional was somewhat interested in what they had found, whereas $22 \%$ (17/76) felt they were very interested, $16 \%(12 / 76)$ felt they were not too interested, $9 \%$ (7/76) felt that their doctor or health care professional was not at all interested, and $3 \%$ (2/76) did not know.

\section{Discussion}

The 3 objectives of this study were to (1) ascertain parents general Internet usage patterns, (2) identify the nature of the information parents most frequently searched for, and (3) determine the impact Internet-sourced information had on parents of children with rare conditions. All objectives were met and are discussed in the following sections.

\section{Internet Use}

All respondents were frequent and competent users of information and communication technology; all of them had an email account, and most $(94.6 \%, 106 / 112)$ had a Facebook account. Respondents mostly searched the Internet from home, late in the evening, and were practiced at finding the information they sought; these patterns of general Internet usage concurred with similar literature $[14,15]$.

This study found that parents were discerning when searching the Internet by comparing the content they found with their own experiences and knowledge. They took many factors into account such as the relevancy and accuracy of the information, how trustworthy and up to date it was, and who was disseminating the information; these judicious parent characteristics have been reported by others [14,16-18]. 
The parents in this study were well educated, and $90 \%$ of their children had a specific diagnosis. Despite this, respondents still accessed numerous sites seeking information regarding their child's condition, prognosis, and management and to ask questions, a finding supported by Roche and Skinner [19] and others $[8,16,20-22]$.

This study sought data on respondents' information needs at 2 stages: at the time of their child's diagnosis and at present. Although there was some variation across the 2 timelines significantly, the highest ranked item remained my child's condition or symptoms. Similarly, there was consistency regarding the top 5 ranked information needs at the 2 timelines (Table 5). Pelentsov et al [23] have confirmed that despite the diverse characteristics of rare conditions, there is consistency regarding the common unmet needs of parents of children with rare conditions.

\section{Impact}

The most significant impact of Internet-sourced information was the empowering effect it had on parents, particularly their improved understanding of their child's condition. Internet-sourced information enabled them to explain their child's condition and improved their ability to manage and care for their child. Some studies reported that Internet-sourced information resulted in parents changing their health care professional $[19,24,25]$, which was also the case for $9 \%$ parents in this study (Table 6).

\section{Parents Disseminating Internet-Sourced Information}

In this study, parents not only engaged with and consumed Internet-sourced information for their own needs, but they were active disseminators of newly sourced information about their child's condition to their health care professionals and wider support network. Social media, Facebook in particular, provided instant access to other parents of children with rare conditions. In this study, the majority (86\%) of those registered in a relevant Web-based forum or network shared information about their child's condition. Traditionally peer support has been in the form of mailing lists, newsletters, discussion fora, and chat rooms [26]. However, it was evident in this study that Web-based engagement and exchange of information with other parents provided support and created a sense of belonging, which in turn reduced the feeling of exclusion, as has been reported by others $[3,7,10,17,19,20,27-29]$.

Respondents were likely to talk to their health care professional about information they uncovered on the Internet, although not all health care professionals were interested in their findings. Few considered that the information had helped educate their health care professional, which is reported by others [30,31]. These findings were somewhat surprising, as even in 2002 doctors were being advised to be prepared to ask parents about their information needs and to discuss Internet use with them [32]. This lack of health care professional-parent exchange to determine what information parents are currently seeking and uncovering might be a missed opportunity in health care consultations and possibly improved child outcomes whereby health care professionals might better determine what services or supports parents require.

\section{Implications}

Implications for health care practice include the impact Internet-sourced information is having on parent-health care professional dynamics. These include how information is shared, health care professionals' interaction with parents when parents share with them the information they have sourced, and the subsequent changing nature of parents' management of their child's condition.

In this study, parents of children with rare conditions identified a number of key factors that should be considered when developing an Irish website. These include ensuring the following:

- The content is relevant, accurate, trustworthy, and up to date.

- The topics most frequently searched for (Table 5) are addressed.

- It contains a Web-based forum or a social network component.

- The website is integrated with social media and is mobile friendly.

These are fundamental factors considering that Internet-sourced information directly influences and impacts on parents (Table 6) and parents disseminate information widely to their health care professionals and to other parents and relevant networks.

\section{Limitations}

As this was an Internet survey and participation was voluntary, it was not representative of all parents of children with rare conditions and most likely attracted participation from parents who were competent Internet users. The questionnaire consisted of 45 questions, and parents who had more than 1 child with a rare condition were asked to complete another 8 questions per additional child (Table 1). The length of the questionnaire might have contributed to the attrition of respondents as they progressed through the questionnaire. As the questionnaire was available on the Internet, it was accessed and completed by parents residing outside of Ireland (Table 2). Parents were asked which Internet-sourced information they sought during 2 phases in their child's life: at the time of diagnosis and at present. However, this question was posed at 1 timepoint (at present) and parents were asked to retrospectively recall what information they were seeking when their child was first diagnosed. Nonetheless, this study did provide an insight into what parents used the Internet for and its impact. Further research into the relevance of information available to parents of children with rare conditions, the impact of Internet-sourced information on parents, the health care professionals' response to parents, and the use of social media in parent-to-parent support is recommended.

\section{Conclusions}

The findings of this study add to the body of emerging research that gives an insight into the use of, and reason for using, the Internet and information and communications technology by parents of children with rare conditions and the ever evolving parent-to-parent support systems (social and intellectual) via social media. What appears evident is that Internet and social 
media engagement facilitates the emergence of parents who are better informed and empowered, have greater understanding of the management and care of rare conditions, and are increasingly considered experts in their child's care, specifically in how the particular condition is developing in their child [6]; many parents come prepared to health consultations with information sourced from the Internet [1].

\section{Acknowledgments}

This study was funded by the Saoirse Foundation. The research team is most appreciative of the parents who participated in this study.

\section{Conflicts of Interest}

None declared.

\section{Multimedia Appendix 1}

[PDF File (Adobe PDF File), 73KB-Multimedia Appendix 1]

\section{Multimedia Appendix 2}

[PDF File (Adobe PDF File), 36KB-Multimedia Appendix 2]

\section{References}

1. Fergie G, Hilton S, Hunt K. Young adults' experiences of seeking online information about diabetes and mental health in the age of social media. Health Expect 2015 Dec 08;19(6):1324-1335. [doi: 10.1111/hex.12430] [Medline: 26647109]

2. van den Bree MB, Miller G, Mansell E, Thapar A, Flinter F, Owen MJ. The internet is parents' main source of information about psychiatric manifestations of 22q11.2 deletion syndrome (22q11.2DS). Eur J Med Genet 2013 Aug;56(8):439-441 [FREE Full text] [doi: 10.1016/j.ejmg.2013.05.001] [Medline: 23707654]

3. Pelentsov LJ, Laws TA, Esterman AJ. The supportive care needs of parents caring for a child with a rare disease: a scoping review. Disabil Health J 2015 Oct;8(4):475-491. [doi: 10.1016/j.dhjo.2015.03.009] [Medline: 25959710]

4. Dragusin R, Petcu P, Lioma C, Larsen B, Jørgensen HL, Cox IJ, et al. FindZebra: a search engine for rare diseases. Int J Med Inform 2013 Jun;82(6):528-538. [doi: 10.1016/j.ijmedinf.2013.01.005] [Medline: 23462700]

5. Powell J, Inglis N, Ronnie J, Large S. The characteristics and motivations of online health information seekers: cross-sectional survey and qualitative interview study. J Med Internet Res 2011 Feb;13(1):e20 [FREE Full text] [doi: 10.2196/jmir.1600] [Medline: 21345783]

6. Nicholl H, Doyle C, Begley T, Murphy M, Lawlor A, Malone H. Developing an information leaflet on 22q11.2 deletion syndrome for parents to use with professionals during healthcare encounters. J Spec Pediatr Nurs 2014 Jul;19(3):238-246. [doi: 10.1111/jspn.12078] [Medline: 24674229]

7. Anderson RP, Elliott EJ, Zurynski YA. Australian families living with rare disease: experiences of diagnosis, health services use and needs for psychosocial support. Orphanet J Rare Dis 2013 Feb 11;8:22 [FREE Full text] [doi: 10.1186/1750-1172-8-22] [Medline: 23398775]

8. Nieuwboer CC, Fukkink RG, Hermanns JM. Peer and professional parenting support on the Internet: a systematic review. Cyberpsychol Behav Soc Netw 2013 Jul;16(7):518-528. [doi: 10.1089/cyber.2012.0547] [Medline: 23659725]

9. Binford Hopf RB, Le Grange D, Moessner M, Bauer S. Internet-based chat support groups for parents in family-based treatment for adolescent eating disorders: a pilot study. Eur Eat Disord Rev 2013 May;21(3):215-223. [doi: 10.1002/erv.2196] [Medline: 22949134]

10. Paterson BL, Brewer J, Stamler LL. Engagement of parents in on-line social support interventions. J Pediatr Nurs 2013 Apr;28(2):114-124. [doi: 10.1016/j.pedn.2012.05.001] [Medline: 22710151]

11. Porter A, Edirippulige S. Parents of deaf children seeking hearing loss-related information on the internet: the Australian experience. J Deaf Stud Deaf Educ 2007;12(4):518-529 [FREE Full text] [doi: 10.1093/deafed/enm009] [Medline: 17456507]

12. Tozzi AE, Mingarelli R, Agricola E, Gonfiantini M, Pandolfi E, Carloni E, et al. The internet user profile of Italian families of patients with rare diseases: a web survey. Orphanet J Rare Dis 2013;8:76 [FREE Full text] [doi: 10.1186/1750-1172-8-76] [Medline: 23680013]

13. Massey OT. A proposed model for the analysis and interpretation of focus groups in evaluation research. Eval Program Plann 2011 Feb;34(1):21-28. [doi: 10.1016/j.evalprogplan.2010.06.003] [Medline: 20655593]

14. Hand F, McDowell DT, Mc Dowell DT, Glynn RW, Rowley H, Mortell A. Patterns of internet use by parents of children attending a pediatric surgical service. Pediatr Surg Int 2013 Jul;29(7):729-733. [doi: 10.1007/s00383-013-3317-5] [Medline: 23615872]

15. Rudi J, Dworkin J, Walker S, Doty J. Parents' use of information and communications technologies for family communication: differences by age of children. Inf Commun Soc 2014 Jul 02;18(1):78-93. [doi: 10.1080/1369118X.2014.934390] 
16. Oprescu F, Campo S, Lowe J, Andsager J, Morcuende JA. Online information exchanges for parents of children with a rare health condition: key findings from an online support community. J Med Internet Res 2013;15(1):e16 [FREE Full text] [doi: 10.2196/jmir.2423] [Medline: 23470259]

17. Glenn AD. Using online health communication to manage chronic sorrow: mothers of children with rare diseases speak. $\mathbf{J}$ Pediatr Nurs 2015;30(1):17-24 [FREE Full text] [doi: 10.1016/j.pedn.2014.09.013] [Medline: 25316198]

18. Ladd D. General and health information challenges of patients with rare diseases: the importance of health information provision and web sites for locating rare disease resources. J Hosp Librariansh 2015 May 05;15(2):189-197. [doi: $10.1080 / 15323269.2015 .1014762]$

19. Roche MI, Skinner D. How parents search, interpret, and evaluate genetic information obtained from the internet. J Genet Couns 2009 Apr;18(2):119-129 [FREE Full text] [doi: 10.1007/s10897-008-9198-4] [Medline: 18937062]

20. Kingsnorth S, Gall C, Beayni S, Rigby P. Parents as transition experts? Qualitative findings from a pilot parent-led peer support group. Child Care Health Dev 2011;37(6):833-840. [doi: 10.1111/j.1365-2214.2011.01294.x] [Medline: 22007983]

21. Niela-Vilén H, Axelin A, Salanterä S, Melender HL. Internet-based peer support for parents: a systematic integrative review. Int J Nurs Stud 2014 Nov;51(11):1524-1537. [doi: 10.1016/j.ijnurstu.2014.06.009] [Medline: 24998788]

22. Nölke L, Mensing M, Krämer A, Hornberg C. Sociodemographic and health-(care-)related characteristics of online health information seekers: a cross-sectional German study. BMC Public Health 2015 Jan 29;15(1):31 [FREE Full text] [doi: 10.1186/s12889-015-1423-0] [Medline: 25631456]

23. Pelentsov LJ, Fielder AL, Laws TA, Esterman AJ. The supportive care needs of parents with a child with a rare disease: results of an online survey. BMC Fam Pract 2016 Jul 21;17(1):88 [FREE Full text] [doi: 10.1186/s12875-016-0488-x] [Medline: 27439905]

24. Leonard H, Slack-Smith L, Phillips T, Richardson S, D'Orsogna L, Mulroy S. How can the Internet help parents of children with rare neurologic disorders? J Child Neurol 2004 Nov;19(11):902-907. [doi: 10.1177/08830738040190110901] [Medline: $\underline{15658796]}$

25. Skinner D, Schaffer R. Families and genetic diagnosis in the genomic and Internet age. Infants Young Child 2006;19(1):16-24 [FREE Full text]

26. Eysenbach G, Powell J, Kuss O, Sa ER. Empirical studies assessing the quality of health information for consumers on the world wide web: a systematic review. J Am Med Assoc 2002;287(20):2691-2700. [Medline: 12020305]

27. McGarvey B, Hart C. Rehab. 2008. An investigation into the social support needs of families who experience rare disorders on the island of Ireland URL: http://www.rehab.ie/about/PDFS/July2008/RehabCare RD Report.pdf [accessed 2017-02-15] [WebCite Cache ID 6oJ2cW1Eu]

28. Gundersen T. 'One wants to know what a chromosome is': the internet as a coping resource when adjusting to life parenting a child with a rare genetic disorder. Sociol Health Illn 2011 Jan;33(1):81-95 [FREE Full text] [doi:

10.1111/j.1467-9566.2010.01277.x] [Medline: 20937053]

29. Hall JG. The role of patient advocacy/parent support groups. S Afr Med J 2013 Oct 11;103(12):1020. [doi: 10.7196/samj.6976]

30. Powell J, Inglis N, Ronnie J, Large S. The characteristics and motivations of online health information seekers: cross-sectional survey and qualitative interview study. J Med Internet Res 2011 Feb;13(1):e20 [FREE Full text] [doi: 10.2196/jmir.1600] [Medline: 21345783]

31. Schieppati A, Henter JI, Daina E, Aperia A. Why rare diseases are an important medical and social issue. The Lancet 2008 Jun 14;371(9629):2039-2041. [doi: 10.1016/S0140-6736(08)60872-7] [Medline: 18555915]

32. Tuffrey C, Finlay F. Use of the internet by parents of paediatric outpatients. Arch Dis Child 2002 Dec;87(6):534-536 [FREE Full text] [Medline: 12456558]

Edited by G Eysenbach; submitted 05.04.16; peer-reviewed by D McDowell, E Agricola; comments to author 27.07.16; revised version
received 28.10.16; accepted 13.12.16; published 28.02 .17
Please cite as:
Nicholl H, Tracey C, Begley T, King C, Lynch AM
Internet Use by Parents of Children With Rare Conditions: Findings From a Study on Parents' Web Information Needs
J Med Internet Res $2017 ; 19(2):$ e51
URL: $\underline{\text { http://www.jmir.org/2017/2/e51/ }}$
doi: $\underline{10.2196 / j m i r .5834}$
PMID: $\underline{28246072}$

CHonor Nicholl, Catherine Tracey, Thelma Begley, Carole King, Aileen M Lynch. Originally published in the Journal of Medical Internet Research (http://www.jmir.org), 28.02.2017. This is an open-access article distributed under the terms of the Creative Commons Attribution License (http://creativecommons.org/licenses/by/2.0/), which permits unrestricted use, distribution, and reproduction in any medium, provided the original work, first published in the Journal of Medical Internet Research, is properly 
cited. The complete bibliographic information, a link to the original publication on http://www.jmir.org/, as well as this copyright and license information must be included. 